\title{
SKRINING FITOKIMIA SENYAWA METABOLIT SEKUNDER DARI EKSTRAK ETANOL BUAH DELIMA (Punica granatum L.) DENGAN METODE UJI WARNA
}

\author{
Muthmainnah B ${ }^{1}$ \\ ${ }^{1}$ Program Studi D3 Farmasi STIKES Nani Hasanuddin Makassar \\ innabaharuddin@gmail.com \\ DOI: https://doi.org/10.32382/mf.v13i2.880
}

\section{ABSTRAK}

Telah dilakukan penelitian skrining fitokimia ekstrak etanol buah delima (Punica granatum L.) yang diperoleh dari Desa Ongkoe Kabupaten Wajo. Penelitian ini bertujuan untuk mengetahui senyawa metabolit sekunder meliputi flavanoid, alkaloid, terpenoid, steroid, saponin dan tanin pada ekstrak etanol buah delima (Punica granatum L.). Penelitian diawali dengan pengolahan buah delima (Punica granatum L.) menjadi simplisia serbuk dengan melalui tahap sortasi basah, pencucian, pengeringan dan sortasi kering. Selanjutnya penelitian dilakukan dengan menggunakan pelarut etanol 70\% dengan perbandingan 1:3 selama 5 hari dengan metode ekstraksi. Penelitian ini dilakukan dengan mengekstraksi simplisia serbuk buah delima (Punica granatum L.) dengan menggunakan metode maserasi (perendaman) dengan pelarut etanol 70\% sedangkan identifikasi senyawa metabolit sekunder dilakukan skrining fitokimia dengan uji warna menggunakan berbagai pereaksi. Hasil penelitian menunjukkan bahwa senyawa metabolit sekunder pada ekstrak etanol buah delima (Punica granatum L.) positif mengandung flavonoid, alkaloid, terpenoid, saponin dan tanin sedangkan pada uji steroid diperoleh hasil yang negatif. Kesimpulannya yaitu ekstrak etanol buah delima (Punica granatum L.) mengandung flavanoid, alkaloid, terpenoid, saponin dan tanin.

Kata Kunci : Buah Delima (Punica granatum L.), Simplisia serbuk, Maserasi, Skrining Fitokimia, Senyawa Metabolit Sekunder.

\section{PENDAHULUAN}

Indonesia sebagai negara tropis memiliki beraneka ragam tumbuhan yang dapat dimanfaatkan sebanyak-banyaknya untuk kepentingan manusia. Masyarakat Indonesia sejak zaman dahulu telah mengenal tanaman yang mempunyai kandungan obat atau dapat menyembuhkan berbagai macam penyakit (Agustina, dkk. 2016).

Tumbuhan merupakan sumber senyawa kimia baik senyawa kimia hasil metabolisme primer seperti karbohidrat, protein, lemak yang digunakan sendiri oleh tumbuhan tersebut untuk pertumbuhannya, maupun sebagai sumber senyawa metabolit sekunder seperti alkaloid, flavonoid, steroid/terpenoid, saponin dan tanin. Senyawa metabolit sekunder merupakan senyawa kimia yang umumnya mempunyai kemampuan bioaktifitas dan berfungsi untuk mempertahankan diri dari lingkungan yang kurang menguntungkan seperti suhu, iklim, gangguan hama, penyakit tanaman, dan dapat juga digunakan untuk mengobati berbagai jenis penyakit pada manusia (Agustina, dkk. 2016).

Skrining fitokimia merupakan metode yang digunakan untuk mempelajari komponen senyawa aktif yang terdapat pada sampel, yaitu mengenai struktur kimianya, biosintesisnya, penyebarannya secara alamiah dan fungsi biologisnya, isolasi dan perbandingan komposisi senyawa kimia dari bermacam-macam jenis tanaman. Letak geografis, suhu, iklim dan kesuburan tanah suatu wilayah sangat menentukan kandungan senyawa kimia dalam suatu tanaman. Sampel tanaman yang digunakan dalam uji fitokimia dapat berupa daun, batang, buah, bunga dan akarnya yang memiliki khasiat sebagai obat dan digunakan sebagai bahan mentah dalam pembuatan obat modern maupun obat-obatan tradisional (Agustina, dkk. 2016).

Perkembangan ilmu pengetahuan terhadap pengobatan berbasis bioaktif dari tanaman mengalami peningkatan yang pesat. Semakin banyak peneliti yang melakukan eksplorasi terhadap tanaman obat untuk mengetahui berbagai macam kandungan 
senyawa aktif dan manfaatnya bagi peningkatan kualitas kehidupan manusia. Sampai saat ini sudah banyak tanaman obat yang terbukti secara empiris dalam mengobati penyakit (Indrawati, 2013).

Salah satu tumbuhan yang sering digunakan sebagai obat tradisional adalah delima (Punica granatum L.). Delima (Punica granatum L.) adalah tanaman buahbuahan yang mudah tumbuh hampir di semua iklim. Pemanfaatan tanaman ini sebagai obat tradisional sangat bervariasi dan seluruh bagian tanaman delima (Punica granatum $\mathrm{L}$.) ini bisa dimanfaatkan sebagai obat (Wahyuni, dkk. 2013).

Kegunaan delima (Punica granatum L.) ini dalam masyarakat sangat luas, antara lain buahnya digunakan sebagai obat cacing, disentri, astringen, sariawan, sering kencing . Bunganya untuk radang selaput lendir gusi, luka terbuka. Kulit buah untuk luka terbuka, disentri, diare kronik dan biji untuk obat batuk (Widjaya, 2012).

Adapun jurnal yang pernah melakukan penelitian tentang delima (Punica granatum L. ) yang diteliti oleh Febriana Dwi Wahyuni dengan judul "Pengaruh ekstrak nheksan daging buah delima putih (Punica granatum L.) terhadap penurunan kadar kolesterol darah pada tikus putih (Rattus norvegicus L.) dan pemanfaatannya sebagai buku suplemen" yang menunjukkan hasil bahwa pemberian ekstrak n-heksan daging buah delima putih menurunkan kadar kolesterol darah tikus putih (Rattus norvegicus L.) tetapi tidak secara signifikan $(\mathrm{p}=0,266)$.

Oleh karena itu, berdasarkan dari penelitian tentang tanaman delima yang sudah pernah dilakukan, mengacu peneliti untuk melakukan lebih dalam lagi skrining fitokimia senyawa metabolit sekunder terhadap buah delima (Punica granatum L.) yang berasal dari Kabupaten Wajo Sulawesi Selatan sebagai langkah awal untuk mengetahui kandungan senyawa aktif yang terdapat dalam buah delima (Punica granatum L.) yang berperan aktif dalam penyembuhan penyakit.

\section{METODE DAN BAHAN Jenis Penelitian}

Jenis penelitian yang dilakukan adalah penelitian observasi laboratorium dengan metode kualitatif untuk mengetahui senyawa metabolit sekunder dengan sampel penelitian yaitu ekstrak etanol buah delima (Punica granatum L.).

\section{Lokasi dan Waktu Penelitian}

Penelitian ini dilakukan pada bulan Juni 2017 di Laboratorium Biofarmasi Jurusan DIII Farmasi Sekolah Tinggi Ilmu Kesehatan Nani Hasanuddin Makassar.

\section{Populasi dan Sampel}

1. Populasi adalah keseluruhan karakteristik atau sifat tertentu yang dimiliki oleh subyek atau objek yang diteliti. Populasi dari penelitian ini adalah tanaman delima (Punica granatum L.) yang ada di Desa Ongkoe, Kecamatan Belawa, Kabupaten Wajo, Sulawesi Selatan.

2. Sampel adalah bagian dari populasi yang diharapkan mampu mewakili populasi dalam penelitian. Sampel penelitian ini adalah ekstrak etanol buah delima (Punica granatum L.) yang tanamannya ada di Desa Ongkoe, Kecamatan Belawa, Kabupaten Wajo, Sulawesi Selatan.

\section{Alat dan Bahan Penelitian}

1. Alat

Adapun alat yang digunakan dalam penelitian ini adalah : Batang pengaduk, Cawan porselin, Kain penyari, Kipas, Lampu spiritus, Pipet tetes, Plat tetes, Rak tabung, Sendok tanduk, Tabung reaksi, Timbangan analitik, Toples kaca.

\section{Bahan}

Adapun bahan yang digunakan dalam penelitian ini adalah : Asam Asetat Anhidrat ( $\mathrm{CH} 3 \mathrm{CO}$ )2O, Asam Sulfat ( H2SO4), Aquadest (H2O), Etanol $70 \%$ (C2H6O), Etil Asetat (C4H8O2), Besi (III) Klorida $(\mathrm{FeCl} 3)$, Asam Klorida Pekat ( $\mathrm{HCl} \mathrm{P})$, Asam Klorida ( $\mathrm{HCl} 2 \mathrm{~N})$, Sampel Ekstrak, Serbuk Magnesium $(\mathrm{Mg}), \quad$ Pereaksi Mayer, Pereaksi Dragendrof, Pereaksi Wagner.

\section{Pengambilan Sampel}

Sampel berupa buah delima (Punica granatum L.) diperoleh dari Desa Ongkoe, Kecamatan Belawa, Kabupaten Wajo. Waktu pengambilan sampel yakni pada pukul 08:0011:00 pagi. Adapun yang dipilih yaitu buah yang telah masak.

\section{Pengolahan Sampel}


Sampel berupa buah delima (Punica granatum L.) yang telah dikumpulkan disortasi basah lalu dicuci dengan air mengalir, kemudian sampel dikeringkan, setelah kering sampel disortasi kering. Selanjutnya dilakukan proses ekstraksi.

\section{Pembuatan Ekstrak}

Sebanyak 500 gram simplisia buah delima (Punica granatum L.) yang telah dikeringkan lalu di maserasi dengan cara dimasukkan kedalam toples kaca lalu direndam dengan etanol $70 \%$ menggunakan perbandingan 1: 3 dilakukan pengadukan sebanyak 1 kali 24 jam selama 5 hari. Disimpan dalam toples tertutup dan terlindung dari cahaya. Setelah 5 hari dilakukan penyarian untuk memisahkan cairan dari residu kemudian diuapkan hingga diperoleh ekstrak kental.

\section{Identifikasi Golongan Senyawa}

\section{Identifikasi Flavonoid}

1 gram ekstrak sampel dimasukkan kedalam tabung reaksi kemudian ditambahkan $\mathrm{HCl}$ Pekat lalu dipanaskan dengan waktu 15 menit di atas penangas air. Apabila terbentuk warna merah atau kuning berarti positif flavonoid (flavon, kalkon dan auron).

\section{Identifikasi Alkaloid}

2 gram ekstrak sampel dimasukkan kedalam tabung reaksi ditetesi dengan 5 $\mathrm{mL} \mathrm{HCl} 2 \mathrm{~N}$ dipanaskan kemudian didinginkan lalu dibagi dalam 3 tabung reaksi, masing-masing $1 \mathrm{~mL}$. Tiap tabung ditambahkan dengan masingmasing pereaksi. Pada penambahan pereaksi Mayer, positif mengandung alkaloid jika membentuk endapan putih atau kuning. Pada penambahan pereaksi Wagner, positif mengandung alkaloid jika terbentuk endapan coklat. Pada penambahan pereaksi Dragendrof, mengandung alkaloid jika terbentuk endapan jingga.

\section{Identifikasi Terpenoid dan Steroid}

2 gram ekstrak sampel dimasukkan dalam tabung reaksi, lalu ditambahkan dengan $2 \mathrm{~mL}$ etil asetat dan dikocok. Lapisan etil asetat diambil lalu ditetesi pada plat tetes dibiarkan sampai kering. Setelah kering, ditambahkan 2 tetes asam asetat anhidrat dan 1 tetes asam sulfat pekat. Apabila terbentuk warna merah atau kuning berarti positif terpenoid. Apabila terbentuk warna hijau berarti positif steroid.

\section{Identifikasi Saponin}

1 gram ekstrak dimasukkan kedalam tabung reaksi ditambahkan $10 \mathrm{~mL}$ air panas, didinginkan kemudian dikocok kuat-kuat selama 10 detik positif mengandung saponin jika terbentuk buih setinggi $1-10 \mathrm{~cm}$ tidak kurang 10 menit dan pada penambahan 1 tetes $\mathrm{HCl} 2 \mathrm{~N}$, buih tidak hilang.

\section{Identifikasi Tanin}

1 gram ekstrak dimasukkan kedalam tabung reaksi ditambahkan $10 \mathrm{~mL}$ air panas kemudian dididihkan selama 5 menit kemudian filtratnya ditambahkan FeCl3 3-4 tetes, jika berwarna hijau biru (hijau-hitam) berarti positif adanya tanin katekol sedangkan jika berwarna biru hitam berarti positif adanya tanin pirogalol

\section{HASIL DAN PEMBAHASAN}




\section{Hasil Penelitian}

Tabel 1. Hasil Skrining Fitokimia Senyawa Metabolit Sekunder Ekstrak Etanol Buah Delima (Punica granatum L.).

\begin{tabular}{lllc}
\hline \multicolumn{1}{c}{ UJI FITOKIMIA } & \multicolumn{1}{c}{ PEREAKSI } & \multicolumn{1}{c}{ PENGAMATAN } & HASIL \\
\hline \multirow{2}{*}{ Flavonoid } & Mg+ HCl Pekat & Terbentuk warna kuning & + \\
& Mayer & Terbentuk endapan putih & + \\
Alkaloid & Wagner & Terbentuk endapan coklat & + \\
& Dragendrof & Terbentuk endapan jingga & + \\
Terpenoid & Liebermann-burchard & Terbentuk warna kuning & + \\
Steroid & Liebermann-burchard & Tidak terbentuk warna hijau & - \\
Saponin & Air+ HCl & Terbentuk busa stabil & + \\
Tanin & FeCl3 & Terbentuk warna hijau kehitaman & + \\
\hline
\end{tabular}

Dari tabel diatas menunjukkan bahwa hasil skrining fitokimia senyawa metabolit sekunder pada ekstrak etanol buah delima (Punica granatum L.) mengandung positif flavonoid, alkaloid, terpenoid, saponin dan tanin.

\section{Pembahasan}

Pada penelitian ini digunakan Sampel buah delima (Punica granatum L.) yang telah masak sebanyak $3 \mathrm{~kg}$, disortasi basah lalu dicuci dengan air mengalir, kemudian dikeringkan di tempat terbuka tanpa terkena sinar matahari secara langsung. Hal ini dilakukan untuk mengurangi resiko rusaknya komponen kimia dalam buah delima akibat terkena suhu tinggi dari sinar matahari. Buah delima yang sudah dikeringkan kemudian diblender hingga menjadi simplisia serbuk buah delima seberat 500 gram, lalu diekstraksi dengan metode maserasi menggunakan pelarut etanol $70 \%$ selama 5 hari dengan pengadukan sebanyak 1 x 24 jam.

Metode ekstraksi yang digunakan adalah metode maserasi karena merupakan metode sederhana dan sangat cocok untuk menyari bahan yang lembut atau tidak keras serta bahan yang tidak tahan atau rusak karena pemanasan. Pelarut yang digunakan adalah etanol $70 \%$ sebagai cairan penyari karena etanol memiliki kemampuan menyari senyawa pada rentang polaritas yang lebar mulai dari senyawa polar hingga non polar, tidak toksik dibanding dengan pelarut organik lain, tidak mudah ditumbuhi mikroba dan relatif murah ( Widjaya, 2012).
Setelah maserasi dan penyarian ekstrak, selanjutnya adalah pemekatan hasil ekstrak dengan diuapkan secara manual. Hasil yang diperoleh berupa ekstrak kental berwarna coklat pekat sebanyak 150,42 gram. Ekstrak inilah yang akan digunakan untuk skrining fitokimia. Skrining fitokimia bertujuan untuk mengetahui keberadaan golongan senyawa metabolit sekunder yang ada dalam ekstrak.

Pada uji flavonoid sejumlah ekstrak dimasukkan ke dalam tabung reaksi dilarutkan dengan $1 \mathrm{~mL}$ etanol $70 \%$ lalu ditambahkan serbuk magnesium, kemudian ditambahkan $\mathrm{HCl}$ pekat. Tujuan penambahan serbuk magnesium dan $\mathrm{HCl}$ pekat ini untuk mereduksi ikatan glikosida dengan flavonoid. Agar flavonoid bisa diidentifikasi, maka ikatan glikosida dengan flavonoid dalam tanaman harus diputus dengan cara mereduksi ikatan tersebut yang mana hasil yang didapatkan positif karena terbentuk warna kuning. Hal ini sesuai dengan hasil penelitian yang dilakukan oleh Pratiwi yang memperoleh hasil positif.

Pada uji alkaloid sejumlah ekstrak dimasukkan ke dalam tabung reaksi ditetesi dengan $\mathrm{HCl} 2 \mathrm{~N}$ bertujuan untuk menarik alkaloid dari dalam simplisia, alkaloid bersifat basa sehingga dengan penambahan $\mathrm{HCl}$ akan terbentuk garam, lalu dipanaskan dengan tujuan memecahkan ikatan antara alkaloid yang bukan dalam bentuk garamnya, lalu didinginkan, kemudian dilakukan reaksi pengendapan dengan menggunakan tiga pereaksi. Untuk pereaksi Mayer diperoleh hasil positif dengan terbentuknya endapan putih atau kuning. Untuk pereaksi Wagner 
juga hasilnya positif dengan terbentuknya endapan coklat sedangkan pada penambahan pereaksi Dragendorff diperoleh hasil yang positif dengan terbentuknya endapan jingga. Hal ini sesuai dengan hasil penelitian yang dilakukan oleh Widjaya yang memperoleh hasil positif.

Pada uji terpenoid/steroid sejumlah ekstrak dimasukkan sedikit dalam tabung reaksi kecil, lalu di kocok dengan sedikit eter. Lapisan eter diambil lalu diteteskan pada plat tetes dibiarkan sampai kering. Setelah kering, ditambahkan 2 tetes asam asetat anhidrat dan 1 tetes asam sulfat pekat. Apabila terbentuk warna merah atau kuning berarti positif terpenoid. Apabila terbentuk warna hijau berarti positif steroid. Hasil yang didapat positif mengandung terpenoid karena berbentuk warna merah atau kuning. Hal ini sesuai dengan hasil penelitian yang dilakukan oleh Widjaya yang memperoleh hasil positif.

Pada uji saponin sejumlah ekstrak dimasukkan ke dalam tabung reaksi ditambahkan $10 \mathrm{~mL}$ air panas, didinginkan kemudian dikocok kuatkuat selama 10 detik hasil yang didapat positif mengandung saponin karena terbentuk buih setinggi $1 \mathrm{~cm}$ tidak kurang 10 menit dan pada penambahan 1 tetes $\mathrm{HCl} 2 \mathrm{~N}$, buih tidak hilang. Busa yang dihasilkan saponin tidak terpengaruh oleh asam sehingga setelah ditambah $\mathrm{HCl} 2 \mathrm{~N}$ tetap stabil dan busa tidak hilang. Hal ini sesuai dengan hasil penelitian yang dilakukan oleh Widjaya yang memperoleh hasil positif.

Pada uji tanin sejumlah ekstrak dimasukkan ke dalam tabung reaksi ditambahkan $10 \mathrm{ml}$ air panas kemudian dididihkan selama 5 menit kemudian filtratnya ditambahkan $\mathrm{FeCl} 3$ 3-4 tetes. Tanin merupakan senyawa fenolik yang cenderung larut dalam air dan pelarut polar tujuan penambahan $\mathrm{FeCl} 3$ untuk menentukan apakah buah delima mengandung gugus fenol, adanya gugus fenol ditunjukkan dengan warna hijau kehitaman dan biru kehitaman setelah ditambahkan $\mathrm{FeCl} 3$. Hasil yang didapat positif karena terbentuk warna hijau kehitaman. Hal ini sesuai dengan hasil penelitian yang dilakukan oleh Pratiwi yang memperoleh hasil positif.

\section{PENUTUP}

\section{Kesimpulan}

Berdasarkan penelitian yang telah dilakukan maka dapat disimpulkan bahwa skrining fitokimia ekstrak etanol buah delima (Punica granatum L.) mengandung senyawa metabolit sekunder berupa flavonoid, alkaloid, terpenoid, saponin dan tanin.

\section{Saran}

Perlu dilakukan penelitian lebih lanjut mengenai kandungan senyawa pada bagian tanaman Delima (Punica granatum L.) selain pada bagian buah.

\section{DAFTAR PUSTAKA}

Agustina, S., dkk.Skrining Fitokimia Tanaman Obat Di Kabupaten Bima. Indonesia E-Journal of Applied Chemistry. Vol 4 No 1 Th 2016.2016

Ditjen POM.Farmakope Indonesia, Edisi V, Departemen Kesehatan Republik Indonesia, Jakarta.2014

Indrawati, N.Bawang Dayak Si Umbi Ajaib Penakluk Aneka Penyakit, Edisi Pertama, PT. Agromedia Pustaka: Jakarta.2013

Irsyad, M.Standarisasi Ekstrak Etanol Tanaman Katumpangan Air (Peperomia pellucida (L.) Kunth), Skripsi tidak diterbitkan-Jakarta.2013

Fakultas Kedokteran dan Ilmu Kesehatan, UIN Syarif Hidayatullah. Khoirani, N.Karakterisasi Simplisia dan Standardisasi Ekstrak Etanol Herba Kemangi (Ocimum americanum L.), Skripsi tidak diterbitkan-Jakarta.2013

Fakultas Kedokteran dan Ilmu Kesehatan, UIN Syarif Hidayatullah. Khotimah, K.Skrining Fitokimia dan Identifikasi Metabolit Sekunder Senyawa Karpain Pada Ekstrak Metanol Daun Carica pubescens Lenne \& K. Koch Dengan LC/MS (Liquid Chromatoghraphtandem Mass Spectrometry,. Skripsi tidak diterbitkan-Malang, Fakultas Sains dan Teknologi, UIN Maulana Malik Ibrahim.2016

Mukhriani.Ekstraksi, Pemisahan Senyawa, dan Identifikasi Senyawa Aktif. Jurnal Kesehatan. Vol 7 No 2 Th 2014.2014

Putra, W.S.68 Buah Ajaib Penangkal Penyakit, Edisi Pertama, Kata Yogyakarta.2013
27 
Pratiwi, A.I.Manfaat Berkumur Sari Buah Delima Merah (Punica granatum) Terhadap Penurunan Akumulasi Plak Gigi, Skripsi tidak diterbitkanDenpasar, Fakultas Kedokteran Gigi, Universitas Maharaswati.2014

Suparni, I.Herbal Nusantara-1001 Ramuan Tradisional Asli Indonesia, Rapha Publishing: Yogyakarta.2012

Wahyuni, F.D., dkk.Pengaruh Ekstrak Nheksan Daging Buah Delima Putih (Punica granatum) Terhadap Penurunan Kadar Kolesterol Darah Pada Tikus Putih ( Rattus norvegicus
L.) Dan Pemanfaatannya Sebagai Buku Suplemen, Skripsi tidak diterbitkan-Jember, Fakultas Keguruan dan Ilmu Pendidikan, Universitas Jember.2013

Widjaya, A.Uji Antifertilitas Ekstrak Etanol 70\% Biji Delima (Punica granatum L.) Pada Tikus Jantan Strain SpragueDawley Secara In Vivo, Skripsi tidak diterbitkan-Jakarta, Fakultas Kedokteran dan Ilmu Kesehatan, UIN Syarif Hidayatullah.2012 